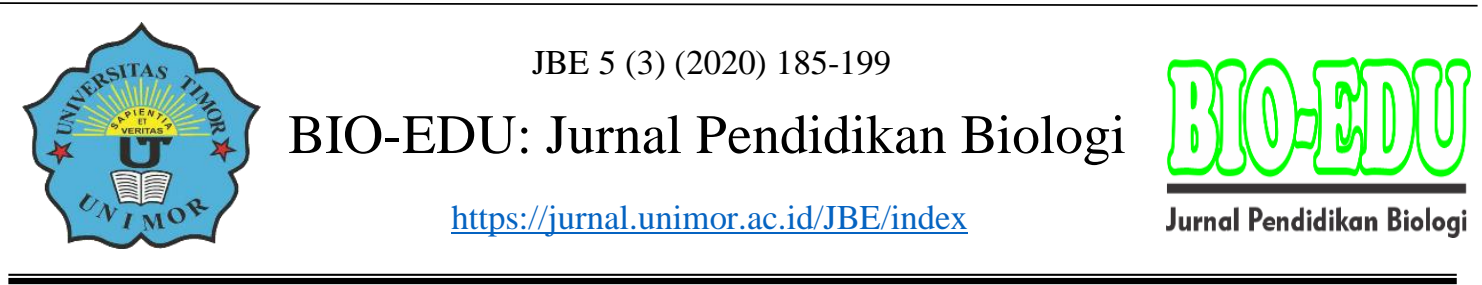

\title{
Analisis Higher Order Thinking Skill dan Self Regulation Biologi Melalui Model Pembelajaran Laps-Heuristik di Kelas XI
}

\author{
Nukhbatul Bidayati Haka ${ }^{1)^{*}}$, Reni Prima Resti' ${ }^{2)}$, Bambang_Sri Anggoro ${ }^{3)}$, \\ Abdul Hamid ${ }^{4)}$, Nur Hidayah ${ }^{5)}$ \\ 1,2,3,4,5 Universitas Islam Negeri Raden Intan Lampung, Bandar Lampung \\ nukhbatulbidayatihaka@radenintan.ac.id
}

DOI: https://DOI 10.32938/jbe. v5i3.615

\begin{abstract}
Abstrak
Penelitian ini bertujuan untuk mengetahui analisis model pembelajaran LAPS-Heuristik terhadap higher order thinking skill peserta didik dan Self Regulation peserta didik Biologi. Peneliti menggunakan metode Quasi Eksperimen dengan menggunakan Pretest-Posttest Control Group Design. Kelas eksperimen yang diberikan perlakuan menggunakan model pembelajaran LAPS-Heuristik dan kelas kontrolnya diberikan model pembelajaran Discovery Learning. Teknik pengambilan sampel dengan cara acak kelas, sampel yang digunakan di kelas XI MIA 4 dan XI MIA 6. Teknik pengumpulan data yang digunakan adalah: tes dan angket. Instrumen yang digunakan dalam penelitian ini menggunakan soal essay Higher Order Thinking Skills dan angket Self Regulation. Hasil penelitian dan pembahasan yang telah didapat bahwa dalam uji hipotesis dengan menggunakan uji MANOVA tersebut didapatkan hasil dengan sig 0,000, dapat dikatakan berhasil dalam menganalisis apabila hasil dari uji hipotesis memiliki signifikan< 0,05 . Dalam hal ini penelitian yang telah dilakukan oleh peneliti dapat menjawab seluruh rumusan masalah yang telah ditentukan pada hasil uji hipotesis pada rumusan masalah dengan memperoleh nilai signifikansi $0,000<$ 0,05. Oleh karena itu dapat disimpulkan bahwa: Terdapat pengaruh dalam menganalisis model LAPSHeuristik Higher Order Thinking Skills dan Self Regulation biologi kelas XI.
\end{abstract}

Kata Kunci: Biologi, higher order thinking skill, LAPS-Heuristik, Self Regulation.

\begin{abstract}
This study aims to determine the analysis of the LAPS-Heuristic learning model on the higher order thinking skills of students and the Self Regulation of Biology students. Researchers used a Quasi Experiment method using a Pretest-Posttest Control Group Design. The experimental class that was given treatment used the LAPS-Heuristic learning model and the control class was given the Discovery Learning learning model. The sampling technique was randomized class, the samples were used in class XI MIA 4 and XI MIA 6. The data collection techniques used were: tests and questionnaires. The instruments used in this study used Higher Order Thinking Skills essay questions and Self Regulation questionnaires. Results of research and discussion in can be found in hypothesis testing by using test MANOVA The results obtained with sig 0,000, can be said to be successful in analyzing if the results of tests of hypotheses have significant $<0,05$. In this case the research that has been carried out by the researcher can answer all the formulations of the problem that have been determined in the results of the hypothesis test on the problem formulation by obtaining a significance value of $0.000<0$, 05. Therefore it can be concluded that: There is an influence in analyzing the LAPS -Heuristic Higher Order Thinking Skills and Self Regulation models of biology class XI.
\end{abstract}

Keywords : Biology, Higher Order Thinking Skill, LAPS-Heuristics, Self Regulation 


\section{PENDAHULUAN}

Kurikulum dan pendidikan merupakan satu kesatuan yang tidak bisa dipisahkan. Kurikulum dan pendidikan merupakan satu kesatuan yang dimana kurikulum merupan acuan bagi sebuah pendidikan. Kurikulum terus menurus berkembang seiring dengan perkembangan teori dan praktik pendidikan. Didalam sebuah negara maju ataupun negara berkembang, pendidikan memiliki peranan penting karena untuk menjamin kelangsungan hidup sebuah negara atau bangsa tersebut. Pendidikan merupakan kebutuhan utama bagi setiap bangsa atau negara. Oleh karena itu saat ini pendidikan harus mengarahkan ke daya saing agar mampu dalam berkompetisi. Tim Pengembangan MKPD (2015) Implementasi pada kurikulum 2013 diharapkan dapat memenuhi tujuan dari pendidikan, yaitu dapat menghasilkan peserta didik yang produktif, peserta didik yang kreatif serta peserta didik yang inovatif, yang akan dibantu dengan adanya pendekatan ilmiah yang dianjurkan oleh teknologi pendidikan. Pendekatan ilmiah ini secara rasioanal dan sistematis, sehingga tujuan pendidikan akan tercapai.Nurjanah Pratiwi, Gardjito (2017).

Hakikat yang terdapat pada pembelajaran biologi idealnya dikembangkan sesuai dengan scientific attitudes, scientific processes dan scientific product. Yeni Suryaningsih (2017). Agar terwujudnya suatu kegiatan pembelajaran yang inovatif pendidik dapat menggunakan model pembelajaran. Dengan menggunakan model pembelajaran peserta didik akan lebih aktif dan kreatif. Selama proses pembelajaran menggunakan model pembelajaran $L A P S$-Heuristik merupakan proses kegiatan pembelajaran yang dimana proses kegiatan belajar mengajar yang berlangsung agar peserta didik aktif dan inofatif yaitu model pembelajarn LAPS-heuristik. Model pembelajaran ini ialah model pembelajaran yang dimana berupa serangkaian pertanyaan yang sifatnya menuntun untuk mencari sebuah solusi dari masalah yang diberikan oleh pendidik. Model pembelajaran ini menekankan untuk mencari alternati-alternatif untuk memecahkan masalah yang dimana berupa pertanyaan-pertanyaan dengan memahami terlebih dahulu apa masalahnya, adakah alternatifnya, adakah manfaatnya, adakah solusi dalam menyelesaikan masalah serta bagaimana baiknya dalam mengerjakannya. Jamil Suprihatiningrum (2016). Aris Shoimin (2017) menyatakan bahwa terdapat empat sintak atau langkah-langkah dalam model pembelajaran ini adalah sebagai berikut: memahami masalah, merencanakan pemecahannya, menyelesaikan masalah sesuai dengan rencana dan memeriksa kembali hasil yang diperoleh (looking back). Oleh karena itu peserta didik memiliki kemampuan untuk memecahkan masalahnya yang dibangun oleh peserta didik itu sendiri.

Berdasarkan penelitian yang telah dilakukan oleh Rahman, Murnaka, \& Wiyanti (2018) dalam penelitiannya menyatakan bahwa penggunaan model LAPS-Heuristik terhadap kemampuan pemecahan masalah dilakukan dengan cara melakukan pretest dan posttest pada kelas eksperimen dan kontrol. Yang pertama untuk nilai pretest pada kelas eksperimennya nilai terendahnya 0 dan nilai tertingginya 40,625, serta rata-ratanya adalah 12,139. Kemudian untuk kelas kontrolnya nilai terendahnya 0, nilai tertingginya 37,500 dan untuk rata-ratanya adalah 17,187 . Kemudian diberi perlakuan dengan menggunakan model pembelajaran LAPS-Heuristik, sehingga diperoleh hasil yaitu, niali posttest untuk kelas eksperimen nilai terendahnya 15,625, nilai tertingginya 100 dan untuk rata-ratanya adalah 45,433. Serta untuk kelas kontrolnya nilai terendahnya 3,125, nilai tertingginya 71,875 dan untuk nilai rata-ratanya adalah 38,822. Dengan demikian bahwa terdapat pengaruhnya dengan menggunakan model pembelajaran ini terhadap kemampuan 
pemecahan masalah, dan dapat dikategorikan dalam kategori baik seta setiap dari proses pembelajaran dapat berjalan dengan baik.

Berdasarkan penelitian yang telah dilakukan oleh Agustianti \& Sukamta (2017) dalam penelitiannya menunjukkan bahwa penerapan model LAPS-Heuristik pada hasil belajar peserta didik adalah sebelum diberi perlakuan untuk nilai rata-rata tes awal (pretest) peserta didik kelas eksperimen adalah 51,98, untuk nilai tertinggi pretest peserta didik adalah 73 serta nilai terendahnya adalah 23. Kemudian nilai rata-rata pada kelas kontrol pretest peserta didik adalah 53,50, untuk nilai tertingginya yaitu 73 dan nilai terendahnya 23. Kemudian setelah diberi perlakuan untuk nilai rata-rata tek akhir (posttest) untuk kelompok ekperimennya adalah 87,73. Untuk nilai tertinggi hasil elajar peserta didik kelompok eksperimen adalah 100, dan untuk nilai terendahnya adalah 77 . Sedangkan untuk nilai rata-rata posttest peserta didik kelas kontrol adalah 71,43 . Nilai tertinggi untuk kelas kontrol adalah 87 dan untuk nilai terendahnya adalah 53. Sedangkan untuk hasil keaktifan peserta didik kelas eksperimen $85 \%$ dinyatakan dengan kategori baik. Dan untuk kelas kontrolnya sebesar $72 \%$ dengan kategori baik.

Model pembelajaran yang perpusat terhadap peseta didik ini terdapat salah satu model pembelajaran yaitu model pembelajaran LAPS-Heuristik. Dalam menyelesaikan sebuah masalah dalam penyelesaiannya peserta didik dituntun terlebih dahulu supaya mengetahui atau memahami apakah ada masalahnya, apakah terdapat alternatifnya, apakah ada bermanfaat, apakah ada solusi dari sebuah masalah dan bagaimana caranya untuk mengerjakannya. Rahman, Murnaka, \& Wiyanti (2018). Pertanyaan-pertanyaan yang dirangkai yang bersifat menuntun dalam mencari solusi dari sebuah solusi dari masalah tersebut disebut dengan heuristik. Model pembelajaran LAPS-Heursitik ialah model pembelajran yang sifatnya menuntun peserta didik dalam pemecahan masalah yang dimana dalam pemecahan masalahnya menggunakan kata tanya, seperti apakah ada masalahnya, apakah ada alternatifnya, adakah manfaatnya serta solusi apa dalam menyelesaikan masalah tersebut. Kemudian terdapat empat sintak dalam model pembelajaran LAPS-Heuristik, yaitu memahami masalah, merencanakan pemecahan masalah, menyelesaikan masalah sesuai dengan rencana dan melihat kembali. Aris Shoimin (2017).

Susan M. Brookhart menyatakan bahwa Higher Order Thinking Skill merupakan suatu tingkatan yang ada pada taksonomi Bloom yang dimana kemampuan bepikirnya terletak pada bagian teratas. Disini peserta didik dituntuk untuk melakukan transfer, yang dimaksud dengan melakaukan transfer ialah peserta didik harus berfikir, yang dimana peserta didik harus menerapkan pengetahuannya yang dikembangkan selama kegiatan pembelajaran berlangsung kedalam konteks yang baru. "Baru" berarti penerapan konsep yang sebelumnya belum pernah terpikirkan oleh peserta didik sebelumnya, tetapi konsep tersebut sudah pernah di ajarkan sebelumnya). Kemampuan berpikir tingkat tinggi menurut susan ini terdiri dari tiga indikator, yaitu menganalisis, mengevaluasi dan mencipta. Brookhart (2010). Model pembelajaran LAPS-Heuristik ini sangat penting untuk meningkatkan Higher Order Thinking Skill peserta didik, karena peserta didik disini tidak hanya mendengarkan atau menerima setiap materi-materi yang diberikan oleh pendidik atau bersifat pasif tetapi peserta didik di tuntut untuk mampu menyalurkan pedapatnya atau berperan aktif untuk membangun atau mengkonstruksikan pengetahuannya, sehingga dalam proses pembelajaran yang sedang berlangsung akan lebih bermakna dan akan lebih lama di ingat oleh peserta didik khususnya pada materi biologi dapat meningkat dan selama proses pembelajaran berlangsung yang bertujuan 
untuk mengkonstruksikan atau menyalurkan ilmu yang mereka dapat agar lebih bermakna.

Self Regulation peserta didik juga dapat ditingkatkan melalui model pembelajaran LAPS-Heuristik. Self Regulation ini dapat diartikan sebagai pengarahan diri atau pengaturan diri dalam berprilaku selama proses pembelajaran. Self Regulation selama proses pembelajaan sangat diperlukan oleh peserta didik karena dapat memotivasi kegiatan belajarnya. Self Regulation merupakan pembelajaran dengan adanya sebab akibat dari sebuah pemikiran, perasaan, strategi serta adanya tingkah laku pada diri seseorang bertujuan terhadap orientasi pada suatu tercapainya sebuah tujuan tersebut. Robert J. Marzano (1993). Selanjutnya Asina Christina Rosito (2018) self regulation mempunyai tiga kategori utamanya, yaitu memiliki rancangan dalam belajar, kemajuan dari belajar pada saat menerapkan sebuah rancangan dapat dipantau serta adanya mengevaluasi hasil belajar dengan lengkap.

Model LAPS-Heuristik dapat juga digunakan dalam peningkatan Self Regulation pada peserta didik. Self Regulation ialah pengarahan diri atau pengaturan diri dalam berprilaku selama kegiatan pembelajaran berlangsung. Self Regulation ini sangat dibutuhkan, Self Regulation dapat memotivasi peserta didik selama proses pembelajaran. Model pembelajaran $L A P S$-Heuristik merupakan model pembelajaran yang diyakini dapat berpengaruh terhadap Higher Order Thinking Skill dan Self Regulation pada peserta didik. Berdasarkan pemaparan tersebut bahwa pemilihan pendidik masih belum tepat dalam memilih model pembelajaran, serta masih rendahnya Higher Order Thinking Skill dan Self Regulation peserta didik. Penelitian ini bertujuan untuk mengetahui penggunaan model pembelajaran LAPS-Heuristik Higher Order Thinking Skill biologi Kelas XI, untuk mengetahui penggunaan model pembelajaran LAPS-Heuristik terhadap Self Regulation biologi Kelas XI, untuk mengetahui penggunaan model pembelajaran LAPS-Heuristik terhadap Higher Order Thinking Skill dan Self Regulation biologi Kelas XI.

\section{METODE}

Dalam penelitian ini menggunakan metode Quasi Eksperimen atau eksperimen semu, dengan jenis penelitiannya menggunakan desain Pretest-Posttest Control Group Design. Yang dimana terdapat dua kelas yang pemilihannya secara acak (random), selanjutnya diberi perlakuan pretest bertujuan untuk mengethui keadaan awal peserta didik apakah terdapatnya perbedaan antara kelas eksperimen dengan kelas kontrol. Sugiyono (2017). Penelitian ini akan dilaksanakan di SMA Al-Kautsar Bandar Lampung, Jalan Soekarno Hatta, Rajabasa, Kota Bandar lampung, tahun 2019/2020. Peneliti ini dilaksanakan pada semester ganjil, tanggal 16 oktober sampai tanggal 4 november tahun 2019.

Penelitian ini menggunakan dua kelas subjek penelitian, yaitu penelitian kelas eksperimen yang dimana kelas ini diberinya perlakuan dengan menggunakan model pembelajaran $L A P S$-Heuristik dan untuk kelas kontrolnya diberikan model pembelajaran Discovery Learning. Subjek yang di butuhkan yaitu siswa kelas XI tahun 2019/2020 berupa XI MIA 4 sebagai kelas Eksperimen dan XI MIA 6 sebagai kelas kontrol dengan jumlah 71 peserta didik.

Penelitian eksperimen ini menggunakan Pretest-Posttest Control Group Design. Jenis design ini memiliki dua kelas yang dipilih secara random. Sehingga peneliti menggunakan dua kelas diantaranya kelas yang diberi perlakuan merupakan kelas eksperimen sedangkan kelas yang tidak diberikan perlakuan disebut kelas kontrol. Pertama, kelas eksperimen ini diberi perlakuan dengan menggunakan model 
pembelajaran $L A P S$-Heuristik. Kedua, kelas kontrol peserta didik mendapat perlakuan dengan menggunakan model pembelajaran Discovery Learning.

Sebelum melakukan pengumpulan data, soal tes diujikan terlebih dahulu untuk mengetahui validitas, reliabilitas, tingkat kesukaran dan uji daya beda menggunakan alat bantu berupa software Microsoft Excel 2010. Data yang di kumpulkaan berupa tes kemampuan berpikir tingkat tinggi yang mengacu pada Susan M. Brokhart. Instrumen yang digunakan berupa tes tertulis berupa soal esay Higher Order Thinking Skill. Teknik pengumpulan data yang di gunakan berupa tes, angket dan dokumentasi. Teknik analisis data untuk mengukur tes Higher Order Thinking Skill diuji dengan uji statistik. Uji statistik yang digunakan berupa uji normalitas, uji homogenitas dan uji hipotesis. Uji hipotesis menggunakan uji MANOVA Aplikasi yang digunakan untuk mengukur tes Higher Order Thinking Skill dengan SPSS 18.

\section{HASIL DAN PEMBAHASAN}

Berdasarkan penelitian, uji validitas diketahui nomer butir soal yang valid berjumlah 11 dari 22 soal. Hasil uji reliabilitas menunjukan 0,77 dikatakan reliabel jika rHitung>rTabel. Pada kategori tingkat kesukaran terdapat 18 soal memiliki tingkat sedang dan 4 soal pada kriteria jelek. Dan uji daya pembeda terdapat 10 soal yang memiliki kriteria jelek, 11 soal dengan kriteria cukup dan 1 soal dengan kriterian baik. Jadi, soal yang digunakan berjumlah 10 soal dengan kriteria valid, reliabilitas 0,77 , tingkat kesukaran sedang, dan daya pembeda cukup. Selanjutnya di lakukan uji prasyarat dan analisis Higher Order Thinking Skill. Rekapitulasi skor hasl tes kemampuan berpikir tingkat tinggi masing-masing peserta didik diubah dalam bentuk persentase, kemudian data yang diperoleh dianalisis menggunakan rumus Normalized Gain ( $N$-Gain) yaitu:

$$
N-\text { Gain }=\frac{\text { Skor Postest }- \text { skor pretest }}{\text { skor maksimal }- \text { skor pretest }}
$$

$N$-Gain/Indeks gain yang diperoleh pada tes Higher Order Thinking Skill dan Self Regulation (pretest dan posttest) menunjukan perubahan atau tidaknya dapat dilihat berdasarkan kriteria pada tabel 1 dibawah ini:

Tabel 1. Perbandingan Nilai Rata-Rata Kemampuan Berpikir Tingkat Tinggi Dan Nilai $N$-Gain Kemampuan Berpikir Tingkat Tinggi Pada Kelas Eksperimen Dan Kelas Kontrol

\begin{tabular}{|c|c|c|c|c|c|c|c|c|}
\hline \multirow[t]{2}{*}{ Keterangan } & \multicolumn{4}{|c|}{ Kelas Eksperimen } & \multicolumn{4}{|c|}{ Kelas Kontrol } \\
\hline & Pretest & Posttest & $\begin{array}{l}N- \\
\text { Gain }\end{array}$ & Kriteria & Pretest & Posttest & $\begin{array}{l}\text { Gain } \\
\text { Gain }\end{array}$ & Kriteria \\
\hline $\begin{array}{l}\text { Nilai Rata- } \\
\text { Rata }\end{array}$ & 38,24 & 82,13 & 0,72 & Tinggi & 40,95 & 79,33 & 0,65 & Sedang \\
\hline $\begin{array}{l}\text { Jumlah } \\
\text { Siswa }\end{array}$ & \multicolumn{4}{|c|}{36 Peserta Didik } & \multicolumn{4}{|c|}{35 Peserta Didik } \\
\hline
\end{tabular}

Sumber: data nilai N-Gain Higher Order Thinking Skill dengan microsoft excel 2010

Berdasarkan tabel 1, menunjukkan bahwa dikelas eksperimen dengan jumlah peserta didik 36 peserta didik, tes pretest dan posttest yang dilakukan menggunakan 10 soal essay sehingga diperoleh nilai rata-rata pretest sebesar 38,24, nilai rata-rata posttest memperoleh 82,13 serta untuk nilai rata-rata $N$-Gainnya yaitu 0,72 dengan masuk kategori tinggi. Kemudian untuk kelas kontrol dengan jumlah peserta didik 35 peserta 
didik, diperoleh nilai rata-rata pretest 40,95 , nilai rata-rata posttest 79,33 dan untuk nilai rata-rata $N$-Gain 0,65 dengan kategori sedang. Nilai posttest kelas eksperimen dan kontrol memiliki perbedaan yang signifikan, nilai posttest kelas eksperimen jauh lebih tinggi dibandingkan dengan kelas kontrol, sama halnya dengan nilai rata-rata $N$-Gainnya, kelas eksperimen lebih tinggi dibandingkan dengan kelas kontrol. Artinya pembelejaran dengan menggunakan model pembelajaran LAPS-Heuristik ini mampu untuk meningkatkan Higher Order Thinking Skill peserta didik.

\section{Tabel 2. Uji Normalitas Data Higher Order Thinking Skill}

\begin{tabular}{llccc}
\hline \multirow{2}{*}{ Kelas } & \multicolumn{4}{c}{ Kolmogorov-Smirnov ${ }^{\mathrm{a}}$} \\
\cline { 2 - 5 } & & Statistic & $\mathrm{df}$ & \multicolumn{1}{c}{ Sig. } \\
\hline Pretest & eksperimen & 0,125 & 36 &, 167 \\
\cline { 2 - 5 } & kontrol & 0,132 & 35 &, 130 \\
\hline \multirow{2}{*}{ Postest } & eksperimen & 0,191 & 36 &, 106 \\
\cline { 2 - 5 } & kontrol & 0,143 & 35 &, 059 \\
\hline
\end{tabular}

Sumber: data pretest dan posttets Higher Order Thinking Skill dengan SPSS 18

Berdasarkan tabel 2 bahwa uji normalitas tes Higher Order Thinking Skill kelas kontrol dan kelas eksperimen memiliki distribusi normal. Karena diperoleh nilai pretest dan posttest kelas kontrol dan eksperimen dengan sig $>0,05$.

Tabel 3. Uji Homogenitas Higher Order Thinking Skill

\begin{tabular}{lrrrrr}
\hline & \multicolumn{1}{c}{$\begin{array}{l}\text { Levene } \\
\text { Statistic }\end{array}$} & df1 & & df2 & \multicolumn{1}{c}{ Sig. } \\
\hline Pretest & 3,361 & 1 & 69 &, 071 \\
\hline Postest &, 185 & 1 & 69 &, 731
\end{tabular}

Sumber: data pretest dan postets Higher Order Thinking Skill dengan SPSS 18

Berdasarkan tabel 3 bahwa uji Homogenitas tes Higher Order Thinking Skill kelas kontrol dan eksperimen memiliki data yang homogen. Karena diperoleh nilai pretest dan posttest kelas kontrol dan eksperimen dengan sig>0,05.

Tabel 4. Perbandingan Rata-Rata Nilai Angket dan N-Gain Self Regulation Kelas Eksperimen dan Kelas Kontrol

\begin{tabular}{|c|c|c|c|c|c|c|c|c|}
\hline \multirow[t]{2}{*}{ Keterangan } & \multicolumn{4}{|c|}{ Kelas Eksperimen } & \multicolumn{4}{|c|}{ Kelas Kontrol } \\
\hline & Pretest & Posttest & $\begin{array}{l}N- \\
\text { Gain }\end{array}$ & Kriteria & Pretest & Posttest & $\begin{array}{l}N- \\
\text { Gain }\end{array}$ & Kriteria \\
\hline $\begin{array}{c}\text { Nilai Rata- } \\
\text { Rata }\end{array}$ & 69,51 & 87,29 & 0,57 & Sedang & 67,04 & 81,92 & 0,43 & Sedang \\
\hline $\begin{array}{l}\text { Jumlah } \\
\text { Siswa }\end{array}$ & \multicolumn{4}{|c|}{36 Peserta Didik } & \multicolumn{4}{|c|}{35 Peserta Didik } \\
\hline
\end{tabular}

Berdasarkan tabel diatas, menunjukkan bahwa dikelas eksperimen dengan jumlah peserta didik 36 peserta didik, tes pretest dan posttest yang dilakukan menggunakan 20 pertanyaan sehingga diperoleh nilai rata-rata pretest sebesar 69,51, nilai rata-rata posttest memperoleh 87,29, serta untuk nilai rata-rata $N$-Gainnya yaitu 0,57 dengan masuk kategori sedang. Kemudian untuk kelas kontrol dengan jumlah peserta didik 35 peserta 
didik, diperoleh nilai rata-rata pretest 67,04 , nilai rata-rata posttest 81,92 , dan untuk nilai rata-rata $N$-Gain 0,43 dengan kategori sedang. Nilai posttest kelas eksperimen dan kontrol memiliki perbedaan yang signifikan, nilai posttest kelas eksperimen jauh lebih tinggi dibandingkan dengan kelas kontrol, sama halnya dengan nilai rata-rata $N$-Gainnya, kelas eksperimen lebih tinggi dibandingkan dengan kelas kontrol. Artinya pembelejaran dengan menggunakan model pembelajaran LAPS-Heuristik ini mampu untuk meningkatkan Self Regulation peserta didik.

Tabel 5. Uji Normalitas Self Regulation

\begin{tabular}{llrrrr}
\hline & \multirow{2}{*}{ Kelas } & \multicolumn{3}{c}{ Kolmogorov-Smirnov $^{\mathrm{a}}$} \\
\cline { 3 - 6 } & & Statistic & df & \multicolumn{1}{c}{ Sig. } \\
\hline Pretest & eksperimen &, 134 & 36 & 0,134 \\
\cline { 2 - 5 } & kontrol &, 117 & 35 & 0,146 \\
\hline Postest & eksperimen &, 137 & 36 & 0,137 \\
\cline { 2 - 5 } & kontrol &, 088 & 35 & 0,89 \\
\hline
\end{tabular}

Sumber: data pretest dan posttets Self Regulation dengan SPSS18

Berdasarkan tabel 5 bahwa uji normalitas tes Self Regulation dan eksperimen memiliki distribusi normal. Karena diperoleh nilai pretest dan posttest kelas kontrol dan eksperimen dengan sig $>0,05$.

Tabel 6. Uji Homogenitas Self Regulation

\begin{tabular}{lccccc}
\hline & $\begin{array}{l}\text { Levene } \\
\text { Statistic }\end{array}$ & df1 & & df2 & Sig. \\
\hline Pretest & 6,337 & 1 & 69 & 0,070 \\
\hline Postest &, 547 & 1 & 69 & 0,301 \\
\hline Sumber: data pretest dan posttets Self Regulation dengan & SPSS18
\end{tabular}

Berdasarkan tabel 6 bahwa uji Homogenitas tes Self Regulation kelas kontrol dan eksperimen memiliki data yang homogen. Karena diperoleh nilai pretest dan posttest kelas eksperimen dan kontrol dengan sig $>0,05$.

Tabel 7. Uji Multivariate Test (MANOVA)

\begin{tabular}{lllllll}
\hline Effect & & Value & F & Hypothesis df & Error df & Sig \\
\hline Intercept & Pillai's Trace & 0,985 & $2187,987^{\text {a }}$ & 2,000 & 68,000 & 0,000 \\
\cline { 2 - 7 } & Wilks' Lambda & 0,015 & $2187,987^{\text {a }}$ & 2,000 & 68,000 & 0,000 \\
\cline { 2 - 7 } & Hotelling's Trace & 64,353 & $2187,987^{\text {a }}$ & 2,000 & 68,000 & 0,000 \\
\cline { 2 - 7 } & $\begin{array}{l}\text { Roy's Largest } \\
\text { Root }\end{array}$ & 64,353 & $2187,987^{\text {a }}$ & 2,000 & 68,000 & 0,000
\end{tabular}

Sumber: data pretest dan posttets Higher Order Thinking Skill dan self regulation dengan SPSS 18

Setelah melakukan pehitungan uji normatitas data dan homogenitas data, memiliki data yang normal dan homogen, uji prasyarat yang menunjukkan data yang diperoleh selama penelitian normal atau tidak, homogen atau tidak. Setelah data normal dan homogen maka dilanjutkan perhitungan ke uji MANOVA. Uji MANOVA ini digunakan untuk melihat ada atau tidaknya perbedaan pada variabel bebas (Model Pembelajaran LAPS-Heuristik) terhadap varibel terikatnya yaitu Higher Order Thinking Skill dan self regulation. 
Terdapat langkah-langkah atau sintak selama proses pembelajaran berlangsung dengan menggunakan model pembelajaran LAPS-Heuristik terhadap Higher Order Thinking Skill dan Self Regulation, yaitu sebagai berikut:
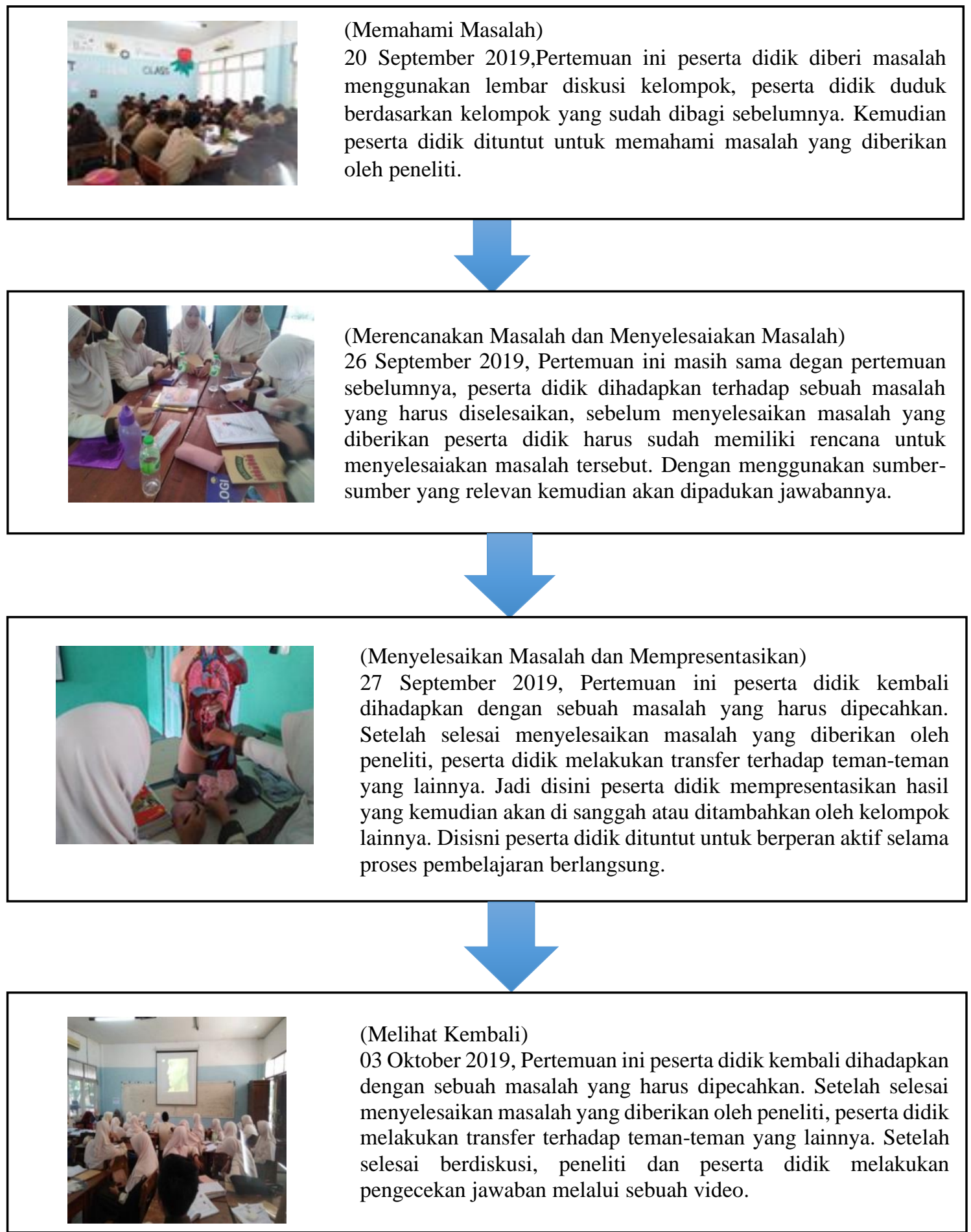

\section{Gambar 1. Langkah-Langkah Model LAPS-Heuristik}

Dari Gambar 1 terdapat tahap-tahap atau sintak dari model pembelajar LAPSHeuristik, model pembelajaran ini berpusat terhadap peserta didik dalam menyelesaikan masalah yang diberikan, sehingga peserta didik akan lebih aktif dan inovatif selama 
proses pembelajaran berlangsung. Proses pembelajaran menggunakan model pembelajaran $L A P S$-Heuristik dikelas eksperimen pada materi struktur dan fungsi sel sistem pencernaan, terdapat empat sintak, yaitu yang pertama peserta didik memahami masalah yang diberikan oleh peneliti berupa LDK, kedua peserta didik harus merencanakan penyelesaian masalah yang sudah diberikan, ketiga peserta didik harus menyelesaiakan masalah sesuai dengan rencana yang sudah direncanakan, baik menggunakan buku paket yang mereka gunakan atau menggunakan sumber lain seperti internet, kemudian dipadukan antara jawaban yang diperoleh dari buku dan yang diperoleh dari internet. Setelah itu peserta didik menyampaikan hasilnya yang diselesaiakan berdasarkan kelompok masing-masing. Ketika ada jawaban yang belum pas maka kelompok lain bisa menyanggah dan menambahkan dari hasil diskusi mereka, disinilah peserta didik dituntut aktif atau berperan aktif. Setelah diskusi selesai peserta didik membahas atau melihat kembali secara bersama jawaban dengan peneliti dengan yang mereka dapat, pembahasan kembali secara bersama-sama ini akan terdapat adanya umpan balik antara peneliti dan peserta didik, pembahasan secara bersama-sama ini dilakukan dengan cara peneliti menerangkan langsung atau dengan menampilkan video.

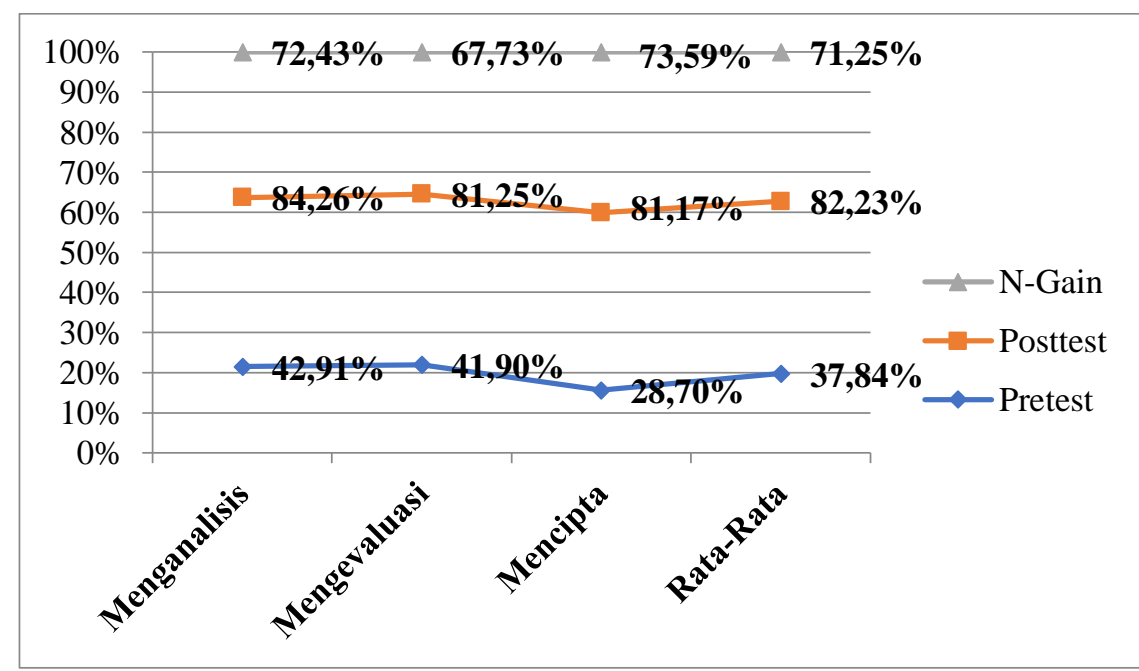

\section{Gambar 2. Peningkatan Rata-Rata Nilai $N$-Gain Perindikator Higher Order Thinking Skill Pada Kelas Eksperimen}

Berdasarkan gambar 2 diatas bahwa terdapat nilai rata-rata dari masing-masing indikator Higher Order Thinking Skill kelas eksperimen yang dimana terdapat nilai pretest terendah yaitu pada indikator mencipta dengan nilai $28,70 \%$ sedangkan untuk nilai posttest tertinggi terdapat pada indikator menganalisis denga nilai $84,26 \%$. 


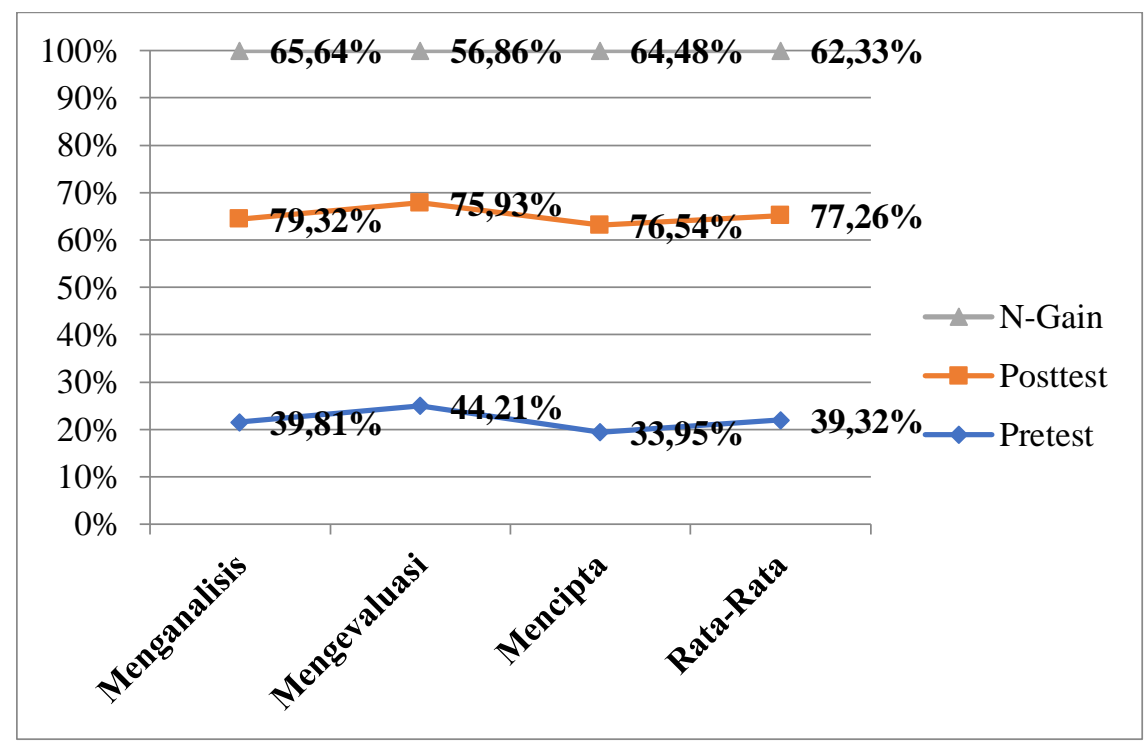

\section{Gambar 3. Peningkatan Rata-Rata Nilai N-Gain Perindikator Higher Order Thinking Skill Pada Kelas Kontrol}

Berdasarkan gambar 3 diatas bahwa terdapat nilai rata-rata dari masing-masing indikator Higher Order Thinking Skill kelas kontrol yang dimana terdapat nilai pretest terendah yaitu pada indikator mencipta dengan nilai 33,95\% sedangkan untuk nilai posttest tertinggi terdapat pada indikator menganalisis denga nilai 79,32\%.

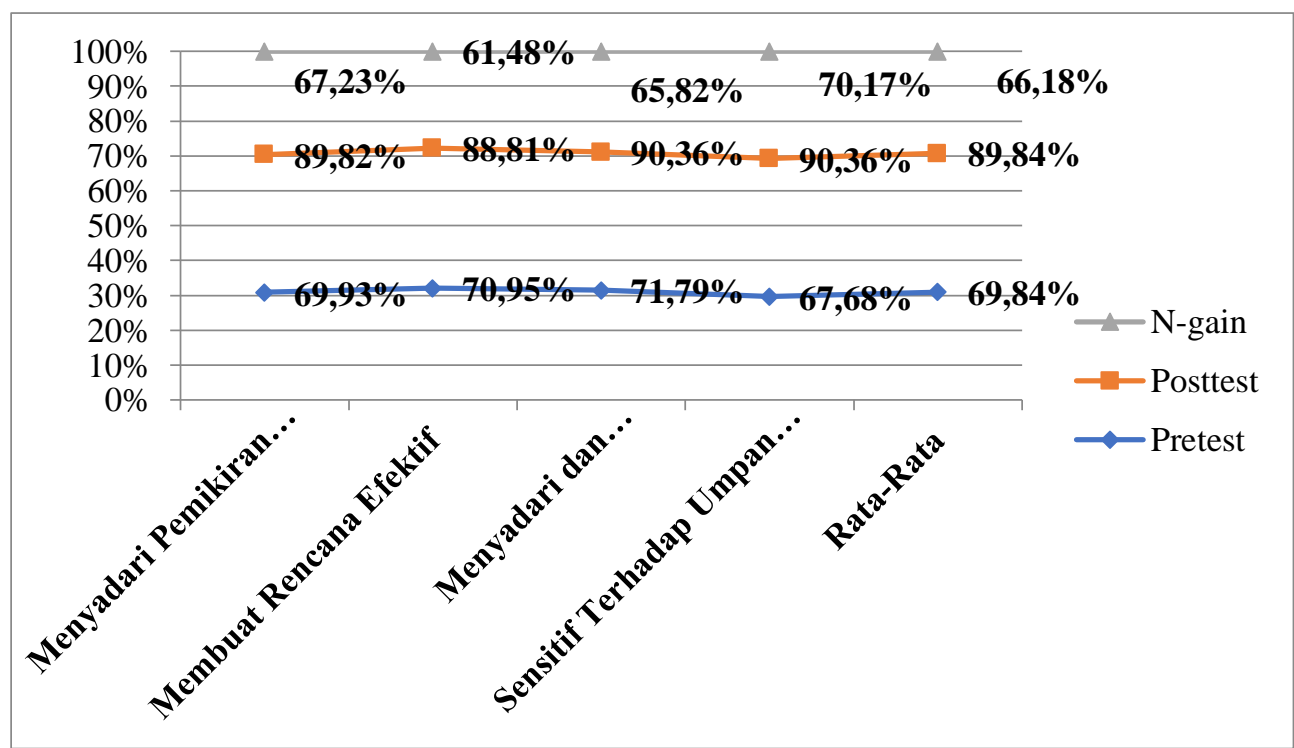

\section{Gambar 4. Peningkatan Rata-Rata Nilai N-Gain Perindikator Self Regulation Kelas Eksperimen}

Berdasarkan gambar 4 diatas bahwa terdapat nilai rata-rata dari masing-masing indikator Self Regulation kelas eksperimen yang dimana terdapat nilai pretest terendah yaitu pada indikator sensitif terhadap umpan balik nilai 67,68\% sedangkan untuk nilai posttest tertinggi terdapat pada indikator Menyadari denga nilai 90,36\%. 


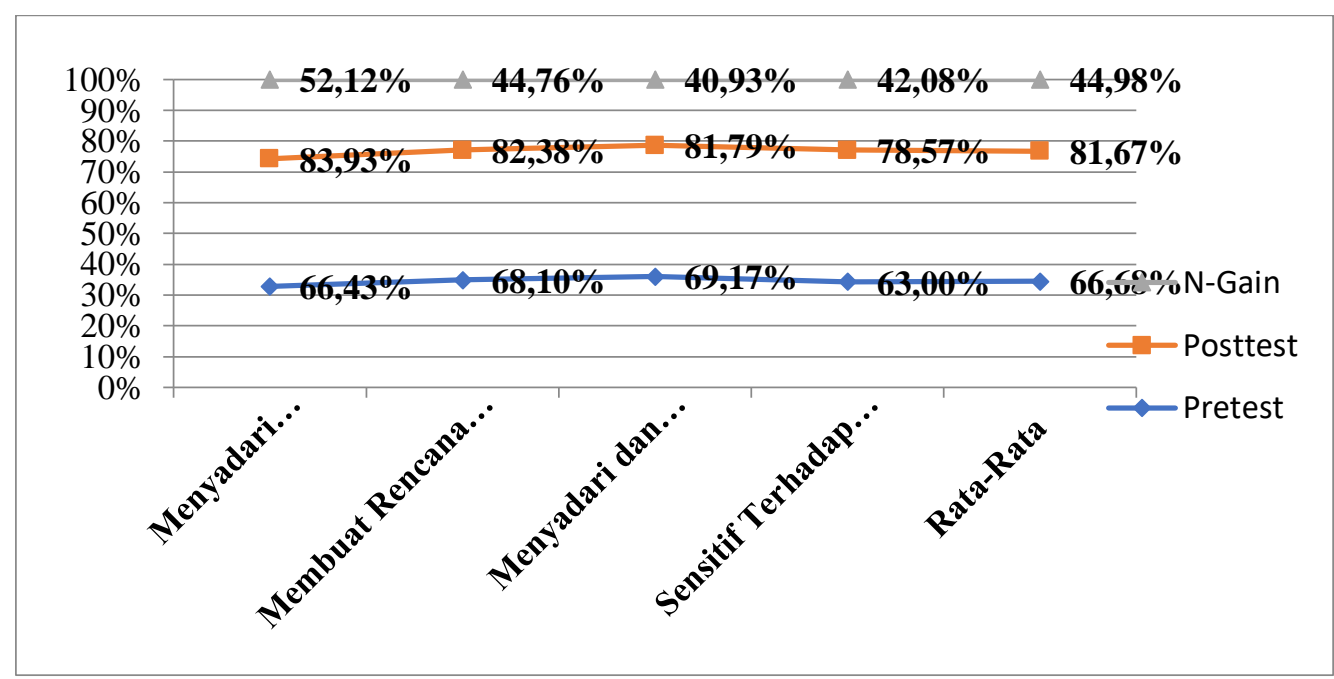

\section{Gambar 5. Peningkatan Rata-Rata Nilai N-Gain Perindikator Self Regulation Kelas Kontrol}

Berdasarkan gambar 5 diatas bahwa terdapat nilai rata-rata dari masing-masing indikator Self Regulation kelas kontrol yang dimana terdapat nilai pretest terendah yaitu pada indikator sensitif terhadap umpan balik dengan nilai 63,00\% sedangkan untuk nilai posttest tertinggi terdapat pada indikator Menyadari pemikiran sendiri denga nilai $83,93 \%$.

Dengan hasil uji hipotesis maka $\mathrm{H}_{0}$ ditolak dan $\mathrm{H}_{1}$ diterima maka pada penelitian ini terdapatnya pengaruh model pembelajaran LAPS-Heuristik terhadap Higher Order Thinking Skill dan self regulation peserta didik kelas XI materi struktur dan fungsi sel sistem pencernaan di SMA Al-kautsar Bandar Lampung.

Penelitian ini menggunakan model pembelajaran LAPS-Heuristik yang dimana model pembelajaran ini merupakan model pembelajaran yang berpusat terhadap peserta didik yang dimana model ini dalam penyelesaian masalahanya menggunakan serangkaian pertanyaan yang menuntun dalam memecahkan masalahnya. Masalah yang diberikan oleh pendidik dapat berupa gambar atau video atau menganalisis sebuah masalah selama proses pembelajaran menggunakan LDK untuk meningkatkan Higher Order Thinking Skill dan self regulation pada materi sistem pencernaan manusia. Dalam menggunakan model pembelajara ini terdapat empat tahapan atau empat sintak selama proses pembelajaran berlangsung, yaitu memahami masalah yang diberikan, merencanakan masalah, menyelesaiakan masalah sesuai dengan rencana dan melihat kembali jawaban yang sudah selesai.

Setelah penelitian ini selesai dilaksanakan, peneliti melakukan analisis data Higher Order Thinking Skill materi sistem pencernaan manusia. Dapat dilihat pada tabel 1 Higher Order Thinking Skill, bahwa terdapatnya perbedaan antara kelas kontrol dengan kelas eksperimen, yang dimana kelas eksperimen nilai rata-rata $\mathrm{N}$-Gain kelas eksperimen lebih tinggi yaitu sebesar 0,72 dengan kriteria tinggi serta untuk kelas kontrol memiliki nilai rata-rata $N$-Gain sebesar 0,65 dengan kategori sedang. Jadi untuk nilai rata-rata posttest dan $\mathrm{N}$-Gain Higher Order Thinking Skill pada materi sistem pencernaan makanan pada manusia kelas eksperimen dan kelas kotrol bahwa nilai kelas eksperimen lebih besar 
atau lebih tinggi dibandingkan dengan kelas kontrol, hal ini terjadi karena penerapan dalam menggunakan model pembelajaran LAPS-Heuristik.

Berdasarkan tabel 4 terdapat nilai rata-rata self regulation dan $N$-gain pada materi struktur dan fungsi sistem pencernaan bahwa nilai rata-rata $\mathrm{N}$-Gain kelas kontrol lebih rendah yaitu dengan nilai 0,43 dengan kategori sedang, dan nilai rata-rata $N$-gain kelas eksperimen lebih tinggi, yaitu sebesar 0,57 dengan kategori sedang. Hal ini kita kaitkan dengan hasiil nilai rata-rata nilai posttest Higher Order Thinking Skill yang dimana kelas eksperimen lebih tinggi dibandingkan dengan kelas kontrol, yang dimana Higher Order Thinking Skill yang dipengaruhi oleh model pembelajaran LAPS-Heuristik ini juga mampu mempengaruhi dari nilai rata-rata self regulation dari setiap peserta didik. Oleh karena itu model pembelajaran LAPS-Heuristik ini mampu untuk meningkatkan Higher Order Thinking Skill dan Self Regulation peserta didik.

Berdasarkan hasil tabel 2 bahwa data Higher Order Thinking Skill kelas kontrol dan kelas eksperimen di peroleh data bahwa pretest dan posttest setelah diuji normalitasnya dengan SPSS 18 menyatakan bahwa data berdisitribusi normal karena nilai sig $>0,05$. Setelah diperoleh data normal maka dilanjutkan uji homogenitas, terdapat pada tabel 3 yang dimana terdapat nilai pretest dan posttest nya dikelas kontrol maupun eksperimen yaitu homogen, karena memperoleh data dengan sig $>0,05$. Sama halnya dengan hasil tabel 5 dan tabel 6 self regulation yang dimana diperoleh data yang normal dan homogen karena data yang diperoleh dengan sig $>0,05$. Setelah diperoleh keseluruhan data normal dan homogen dilanjutkan ke uji hipotesis. Kunci utama penelitian kuantitatif ialah hipotesis, karena hipotesis statistika yang sesuai dengan hipotesis alternatif/satu merupakan hipotesis penelitian yang ditulis dalam kalimat verbal sebagai jawaban sementara terhadap rumusan masalah. Made Putrawan (2017) Uji hipotesisi pada penelitian ini menggunakan uji MANOVA. Yang bertujuan untuk melihat ada atau tidaknya pengaruh model pembelajaran $L A P S$-Heuristik terhadap variabel terikat yaitu Higher Order Thinking Skill dan Self Regulation peserta didik. Terdapat hasil pada tabel 7 bahwa adanya pengaruh model pembelajaran terhadap Higher Order Thinking Skill dan Self Regulation terhadap peserta didik karena diperoleh nilai sig $<0,05$, oleh karena itu terdapatnya pengaruh karena nilai sig tidak lebih dari 0,05 , nilai sig yang diperoleh yaitu sebesar $0,000<0,05$.

Berdasarkan Gambar 1 diatas bahwa pembelajaran menggunakan model LAPSHeuristik ini model pembelajaran yang berpusat kepada peserta didik, disini peserta didik dituntut untuk aktif dalam memecahkan masalah yang sedang dihadapi. Pertama-tama perserta didik di hadapka dengan masalah, setelah peserta didik memahami masalah yang sudah diberikan peserta didik harus merencakan pemecahan dari masalah tersebut. Perencanaan penyeleseaian masalah ini bisa menggunakan buku atau sumber relevan lain sesuai dengan kelompok masing-masing. Kemudian peserta didik dituntut untuk menyelesaikan masalah sesuai dengan rencana yang sudah direncanakan bersama dengan kelompok masing-masing. Setelah itu peserta didik mempresentasikan hasilnya atau melakukan transfer terhadap kelompok lain, setiap kelompok memiliki jawaban yang berbeda-beda, sehingga antara satu keolompok dengan kelompok lain saling melengkapi dengan menyanggah jawaban atau menambahkan jawaban dari kelompok lain. Setelah selesai peneliti dan peserta didik melihat kembali atau membahas kembal menggunakan gambar atau video agar peserta didik mudah untuk memahaminya. 
Berdasarkan gambar 2 dan 3 bahwa nilai rata-rata perindikator Higher Order Thinking Skill kelas kontrol dan eksperimen, diperoleh hasil nilai rata-rata posttest kelas eksperimen lebih besar dibandingkan dengan kelas kontrol selain itu untuk nilai $\mathrm{N}$ gainnya kelas kontrol lebih rendah dibanding dengan kelas eksperimen. Disini berarti bahwa kelas eksperimen dengan menggunakan model LAPS-Heuristik ini mampu meningkatkan indikator Higher Order Thinking Skill lebih tinggi dibandingkan dengan kelas kontrol. Untuk kelas eksperimen nilai tertinggi terdapat pada indikator menganalisis, berarti peserta didik mampu dengan baik untuk menganalsis masalah yang diberikan oleh peneliti. Sedangkan untuk nilai terendah terdapat untuk indikator mencipta, disini peserta didik masih merasa kesulitan untuk menciptakan atau merencanakan dari sebuah masalah yang diberikan, karena peserta didik masih belum terbiasa menggunakan indikator Higher Order Thinking Skill yang dibantu menggunakan model LAPS-Heuristik, sehingga peserta didik merasa kesulitan untuk indikator tersebut. Selain itu indikator mencipta merupakan indikator tingkat teratas dari taksonomi bloom, yang belum biasa digunakan sehingga peserta didik masih merasa kesulitan.

Berdasarkan gambar 4 dan 5 bahwa nilai rata-rata perindikator Self Regulation kelas eksperimen dan kontro, diperoleh hasil yang dimana nilai rata-rata kelas eksperimen lebih tinggi dibandingkan dengan kelas kontrol serta untuk nilai $\mathrm{N}$-Gainnya kelas kontrol lebih rendah dibangding dengan kelas eksperimen. Hal ini menunjukkan bahwa terdapatnya pengaruh dengan menggunakan model pembelajaran LAPS-Heuristik selama proses pembelajaran. Untuk kelas eksperimen nilai tertinggi posttest terdapat pada indikator menyadari dan menggunakan sumber-sumber informasi yang diperlukan, yang dimana peserta didik disini menggunakan berbagai sumber untuk menyelesaikan masalah selama proses pembelajaran berlangsung. Sedangkan untuk nilai terendahnya yaitu pada membuat rencana yang efektif, disini peserta didik merasa belum terlalu bisa untuk membuat rencana yang efektif untuk menyelesaikan masalah yang diberikan.

Jacob \& Tuaputty (2019) mengemukakan bahwa kegiatan pembelajaran yang dalam pembelajarannya model pembelajaran problem solving yang digunakan adalah kegiatan pembelajaran yang dimana pusat pembelajarannya berpusat kepada peserta didik dengan memalui kerja kelompok atau diskusi. Peserta didik dapat membagi tugas dalam menyelesaikan masalah dan berperak aktif. Dengan menggunakan model LAPS-Heuristik ini peserta didik rasa ingin tahunya akan timbul, serta akan memberikan dampak positif bagi peserta didik. Kemudian Susanti et al., (2016) berpendapat bahwa dalam pemecahan sebuah masalah yang diberikan oleh pendidik dapat dengan menggunakan model pembelajaran $L A P S$-Heuristik dengan model pembelajaran ini yang akan memberi kesempatan kepada peserta didik untuk menyelesaikan sebuah masalah berupa rangkaian pertanyaan-pertanyaan yang dapat digunakan untuk pemecahan masalah.

Menyelesaikan masalah sesuai dengan rencana merupakan sintak ke tiga dari model pembelajaran $L A P S$-Heuristik. Setelah peserta didik menemukan pemecahan masalah, kemudian peserta didik dituntut untuk menyelesaikan masalah sesuai dengan perencanaan pemecahan masalah yang sudah dirancang sebelumnya. Disini peserta didik dituntut untuk berfikir untuk menyelesaikan masalah yang sudah diberikan oleh pendidik, sesuai yang dikemukakan oleh Susan bahwa peserta didik harus mampu melakukan transfer, tidak hanyak mengingat tetapi harus mampu berpikir. Peserta didik dituntut untuk menyelesaikan masalah yang diberikan, hal ini sesuai juga yang dikemukakan oleh Susan dalam pemecahan masalah, sehingga disini lah peserta didik akan menggunakan 
kemampuannya untuk menyelesaikan suatu masalah. Ketika peserta didik mampu untuk berpikir dan menyelesaikan masalah sehingga peserta didik akan mampu berpikir kritis dan Higher Order Thinking Skill pun akan bekerja. Sehingga peserta didik mampu untuk menyelesaikan masalah sesuai dengan indikator yang digunakan, yaitu menganalisis, mengevaluasi dan mengkreasi.

Kemudian (Suryani, 2018:51) juga mengemukakan bahwa dalam penelitiannya bahwa model pembelajaran Logan Avenue Problem Solving-Heuristik ini memberikan dampak positif terhadap hasil belajar peserta didik, yang dimana peserta didik lebih aktif dalam proses pembelajaran, karena disini peserta didik diberi kesempatan dalam mengembangkan dirinya sendiri, serta fokus terhadap pemecahan masalah yang diberikan. Temuan lain juga dipaparkan oleh Gilang Azwardi (2019) bahwa pembelajaran yang berhasil tidak hanya dicapain dari prestasi saja, tetapi pembelajaran yang mampu dikembangkan dan diaplikasikan kedalam kehidupan sehari-hari. kemudian dengan menggunakan model pembelajaran LAPS-Heuristik ini mampu meningkatkan kemampuan pemecahan masalah matematis peserta didik dibandingkan dengan menggunakan model pembelajaran konvensional.

\section{KESIMPULAN DAN SARAN}

\section{Kesimpulan}

Berdasarkan hasil penelitian yang telah diuraikan di atas, dapat disimpulkan bahwa terdapat pengaruh dalam penggunaan model pembelajaran LAPS-Heursitik terhadap Higher Order Thinking Skill dan self regulation peserta didik kelas XI di SMA Al-Kautsar Bandar Lampung pada materi sistem pencernaan manusia.

\section{Saran}

Model Logan Avenue Problem Solving-Heuristik merupakan model pembelajaran yang digunakan untuk memecahakan sebuah masalah yang dimana berupa serangkaian pertanyaan-pertanyaan yang menuntun. Saran yang dapat disampaikan oleh peneliti yaitu harus memperhatikan dengan baik model LAPS-Heuristik agar peserta didik tidak merasa bingung. Dan untuk peneliti sebaiknya menggunakan indikator selain Susan M.Brokhart dan dengan materi yang berbeda sehingga dapat mengetahui apakah dengan materi yang berbeda dapat mempengaruhi.

\section{DAFTAR RUJUKAN}

Agustianti, M. R., \& Sukamta, S. (2017). Penerapan Model Pembelajaran Laps-Heuristik Dengan Media Pembelajaran Lectora Inspire Pada Mata Pelajaran Ipa Kelas VII SMP Negeri 4 Petarukan, Edu Komputika,4(2),38-44.

Aris Shoimin. (2017). 68 Model Pembelajaran INOVATIF dalam Kurikulum 2013, Yogyakarta: AR-RUZZ MEDIA.

Asina Christina Rosito. (2018). Kepribadian dan Self-Regulated Learning. Psikologi, 45(3),189-199.

Brookhart, S. M. (2010). In Your Classroom, Virginia USA: Alexandria.

Gilang Azwardi, R. S. (2019). Peningkatan Kemampuan Pemecahan Masalah Matematis Melalui Model Pembelajaran LAPS-Heuristik. . Mathematics Education Journal, 
2(2),62-68.

Jacob, F. A., \& Tuaputty, H. (2019). Perbedaan Hasil Belajar Siswa kelas VII SMP Negeri

9 Ambon Menggunakan Model Pembelajaran LAPS-Heuristik dan Model Pembelajaran Meands-ends Analysis Dipadukan Dengan media Movie Konsep Ekosistem. Jurnal Biopendix,5(1),96-103.

Jamil Suprihatiningrum. (2016).Strategi Pembelajaran,Yogyakarta:AR-RUZZ MEDIA.

Made Putrawan. (2017). Pengujian Hipotesis Dalam Penelitian-Penelitian,Bandung: Alfabeta.

Nurjanah Pratiwi, Gardjito, A. H. (2017). Pengembangan Majalah Biolgi Sebagai Media Pembelajaran Pada Pokok Bahasan Protista Kelas X MIA Di SMA N 7 Kota jambi. Biodik, 3(1),27-34.

Rahman, I. S., Murnaka, N. P., \& Wiyanti, W. (2018). Pengaruh Model Pembelajaran Laps (Logan Avenue Problem Solving)-Heuristik Terhadap Kemampuan Pemecahan Masalah. Wacana Akademika, 2(1),48-60.

Robert J. Marzano. (1993). Assessing Student Outcomes Perfomance Using The Dimensions Of Learning Model. Virginia USA: ASCD President.

Rochimah, S., \& Fatmaryanti, S. D. (2018). Pengembangan Handout Logan Avenue Problem Solving (LAPS-Heuristik) Bermuatan Multi Representasi untuk Meningkatkan Kemampuan Bahasa Simbolik Peserta Didik Kelas XI. Radiasi, 11(2),59-64.

Sugiyono. (2017). Metode Penelitian Pendidikan, Bandung: Alfabeta.

Suryani, I. (2018). Pengaruh Model Pembelajaran Logan Avenue Problem SolvingHeuristik terhadap Hasil Belajar Siswa Kelas VII SMP Negeri 2 Langsa. Jurnal AlQalasadi, 2(2),50-56.

Susanti, W., Nofrianto, A., Amri, M. A., Tinggi, S., Dan, K., \& Pendidikan, I. (2016). Peningkatan Kemampuan Pemecahan Masalah siswa Matematika melalui Model Pembelajaran LAPS- Heuristic DiKelas X SMAN 2. Guntang, 1(2),39-50.

Tim Pengembangan MKPD. (2015). Kurikulum dan Pendidikan. Jakarta: Raja Grafindo Persada.

Yeni Suryaningsih. (2017). pembelajaran Berbasis Praktikum Sebagai Sarana Siswa Untuk Berlatih Menerapkan Keterampilan Proses Sains Dalam Materi Biologi. Bio Education, 2(2),49-57. 